\title{
GIS-INTEGRATED SPATIAL ANALYSIS MODELS FOR IMAGING GEOMORPHOLOGY OF MROGA AND MROŻYCA INTERFLUVIAL AREA (CENTRAL POLAND)
}

\author{
ALEKSANDRA MAJECKA', KAROLINA DMOCHOWSKA-DUDEK ${ }^{2}$
}

\begin{abstract}
GIS data processing techniques are currently being used to revise many ideas in the field of geomorphology and related sciences. The paper presents the characteristics of the landform relief of the Mroga and Mrożyca interfluvial area (on the northern margin zone of the Łódź Plateau) based on the results of GIS spatial analysis models. These are techniques that have not been used so far for such a detailed fragment of the Łódź Plateau. The aim of this paper was to show the possibility of detailing topographic and geomorphological analysis and re-imagining the features of the Łódź Plateau relief on the example of a case study of the Mroga and Mrożyca interfluvial area. In this case, the use of GIS modelling confirmed the main features of the strongly transformed relief of the Mroga and Mrożyca interfluvial area, which is a result of overlapping elements of relief formed during the Warta stadial of the Odra Glaciation and further, during periods of the Vistulian and Holocene morphogenesis.
\end{abstract}

Key words: Geographic Information System, land relief modelling, Mroga and Mrożyca, Łódź Plateau

\section{Introduction}

In terms of geomorphology and palaeogeography, the upper Mroga River catchment area and its vicinity is one of the most studied areas in the Łódź Plateau. Since the 1960s, the region has been used as a study area mainly for research on periglacial (Dylik 1953, 1961, 1967) and river processes (Turkowska 1975, 1976, 1988, 1997). As a result of the long-term research, the post-Wartanian development of the Mroga valley has been considered as a reference for rivers flowing down from the margin zone of the Łódź Plateau. The catchment area of the upper Mroga River includes a feature of glacial relief in the form of moraine plateau, and overlapping features of post-Wartanian relief, including the effects of processes that occurred in the periglacial climate of the Vistulian and the temperate climate of the Holocene. As a result, the study area could be considered as a reference for the landscape on the Łódź Plateau.

Although the area has been surveyed in terms of palaeogeography of the Upper Pleistocene, the aim of this paper is to reanalyse the contemporary relief of the part of the Mroga catchment that covers the Mroga and Mrożyca interfluvial area and to provide a quantitative morphometric analysis based on maps and three-dimensional representations created using GIS spatial analysis models. GIS has proven to be particularly useful in analyses that land relief as an important element. It provides a comprehensive and integrated set of software tools, is open to new solutions and is designed for the analysis of data that have a spatial component (Urbański 2012). GIS land relief analysis is currently the most common cartographic tool in the field of geomorphology. Although 3D modelling and analysis have been used since the 1970s, contemporary 3D GIS systems provide a widespread use of such analysis (Franklin 1987; Raper 1989; Pike et al. 2009).

\section{Materials and methods}

The analysis of the landform relief Mroga and Mrożyca interfluvial area was based on the primary materials available in the form of the Digital Elevation Model (DEM), a 1:10 000 topographic

\footnotetext{
1 University of Warsaw, Faculty of Geology, 02-089 Warsaw, 93 Żwirki and Wigury Av., Poland; e-mail: a.majecka@uw.edu.pl, ORCID: 0000-0002-3911-3155

2 University of Lodz, Faculty of Geographical Sciences, 90-142 Łódź, 31 Kopcińskiego St., Poland; e-mail: karolina.dmochowska@geo.uni.lodz.pl, ORCID: 0000-0001-5869-3960
} 
map and maps elaborated based on detailed geological research (Twardy et al. 2010) and indirectly the 1:50 000 Detailed geological map of Poland (Nowacki 1990, 1993).

The Digital Elevation Model is a digital record of information on land surface altitude based on three-dimensional spatial data - points with the coordinates $\mathrm{x}, \mathrm{y}$ and $\mathrm{z}$, i.e. altitude above sea level (Groshong 2006; Medyńska-Gulij 2012; Żyszkowska et al. 2012). The Digital Elevation Model in the form of ASCII* and TIN files** for the Mroga and Mrożyca interfluvial area was acquired from the Department of Geodesy and Cartography of the Regional Centre of Geodetic and Cartographic Documentation, and includes six sheets (M-34-4-A-d-4, M-34-4-B-c-3, M-34-4-Bc-4, M-34-4-C-b-2, M-34-4-D-a-1, M-34-4-D-a2). On the basis of this model, morphometric features of the modelled relief were determined, and the results were visualised in a 3D representation.

The other primary materials, i.e. the aerial photograph and the digital topographic map (raster data) provided by the Department of Geodesy and Cartography mentioned above, contained spatial reference information. It was therefore possible to georeference them to a map coordinate system. The geomorphological map and the geological map of the study area required digitisation (map scanning and vectorisation) and georeferencing of the digitised data using the existing spatial data (vector feature class) contained in the desired map coordinate system (Nita et al. 2007).

These materials were analysed using the GIS environment and the 3D GIS spatial analysis model was built (Fig. 1). The generated spatial analysis models of the land relief made it possible to capture the main morphological features of the study area. Based on the Digital Elevation Model (DEM), and using the 3D Analyst Tools from the ArcScene software, a tree-dimensional representation of the Mroga and Mrożyca interfluvial area was created and overlaid with the aerial photograph of the terrain surface and vectorised geomorphological and geological maps. A 12-fold coefficient of vertical exaggeration was used in the analysis to enhance the visibility of the relief. Furthermore, the 3D Analyst Tools made it possible to identify the slope (gradient) from each cell of the raster surface. The last element of the analysis consisted in preparing a map presenting the energy of the relief (absolute index expressed in metres, defined as the difference between the maximum and minimum height in a given surface area), based on the grid and selected geomorphological units (Wieczorek, Żyszkowska 2011).

\section{Study area}

The analysis covered a section of the upper Mroga River catchment area. The Mrożyca River is the largest left-bank tributary of the Mroga River and its valley runs parallel to the Mroga Valley. The interfluvial area of the Mroga and Mrożyca covers an area of $c a 87 \mathrm{~km}^{2}$. It stretches over $20 \mathrm{~km}$, from the spring area to the south-east of Brzeziny up to the mouth of the Mrożyca River into the Mroga River near Głowno.

The Łódź Plateau descends towards the north-east. The land relief is highly diverse, which is manifested in altitude differences of $c a$ $85 \mathrm{~m}$ between the highest elevations in the south and the lowest ones in the north. The highest part of the plateau, i.e. $230.2 \mathrm{~m}$ a.s.l., is located near Szymaniszki, and the altitude differences relative to the Mroga bottom reach over $50 \mathrm{~m}$ (the lower Mroga River). The width of the interfluvial area varies - it is narrowest (5 km wide) at the longitude of Kołacin and increases to over $8 \mathrm{~km}$ near Kolonia Niesułków, and gradually becomes narrower again from Nowostawy up to the river fork (Fig. 2).

Due to the heterogeneous land relief in the southern part of the interfluvial area, the GIS spatial analysis conducted by the authors includes the region stretching from the area of Brzeziny in the south to Wola Cyrusowa village in the north ( $\mathrm{ca}$ $10 \mathrm{~km}$ of the latitudinal extent). Figure 3 shows the range of spatial analysis models generated for the research area. The largest area of $127.3 \mathrm{~km}^{2}$ was shown on a hypsometric map using DEM, map of gradient of slopes, map of exposure of slopes, relief energy map. An area of $40 \mathrm{~km}^{2}$ is shown in a 3D geomorphological model and in a map of the land relief energy of denudation valleys.

\footnotetext{
${ }^{*}$ ASCII (American Standard Code for Information Interchange) files contain series or collection of points with $\mathrm{x}-, \mathrm{y}-$, and associated z-values.

** TIN (triangulated irregular network) files depict geographic surfaces as contiguous non-overlapping triangles used to match the elevation of a terrain exactly.
} 
PRIMARY DATA
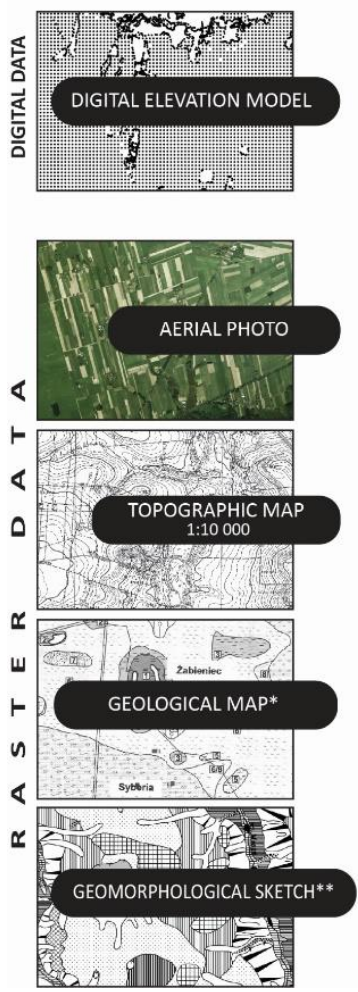

\section{GIS DATABASE}
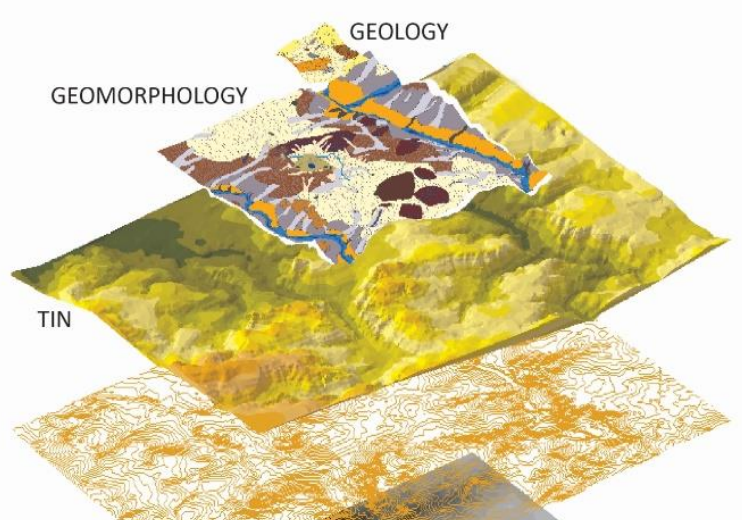

CONTOURS

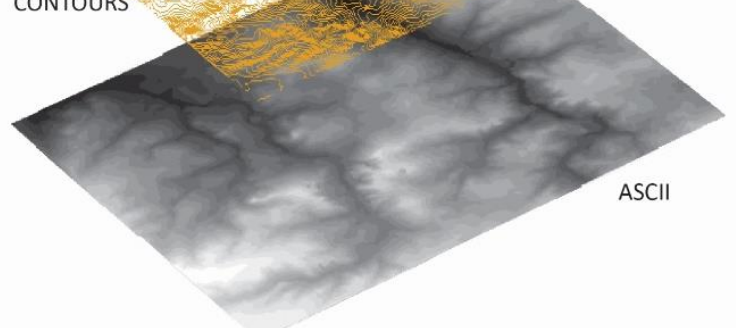

GIS SPATIAL ANALYSIS

\section{HYPSOMETRY \\ (ELEVATION)}

ASPECT

OF SLOPES

\section{SLOPES}

PROFILE

CURVATURE

RELIEF

ENERGY

\section{ELEVATION}

Fig. 1. GIS spatial analysis model of Mroga and Mrożyca interfluvial area

* geological map according to Twardy et al. (2010)

** geomorphological sketch according to Twardy et al. (2010)

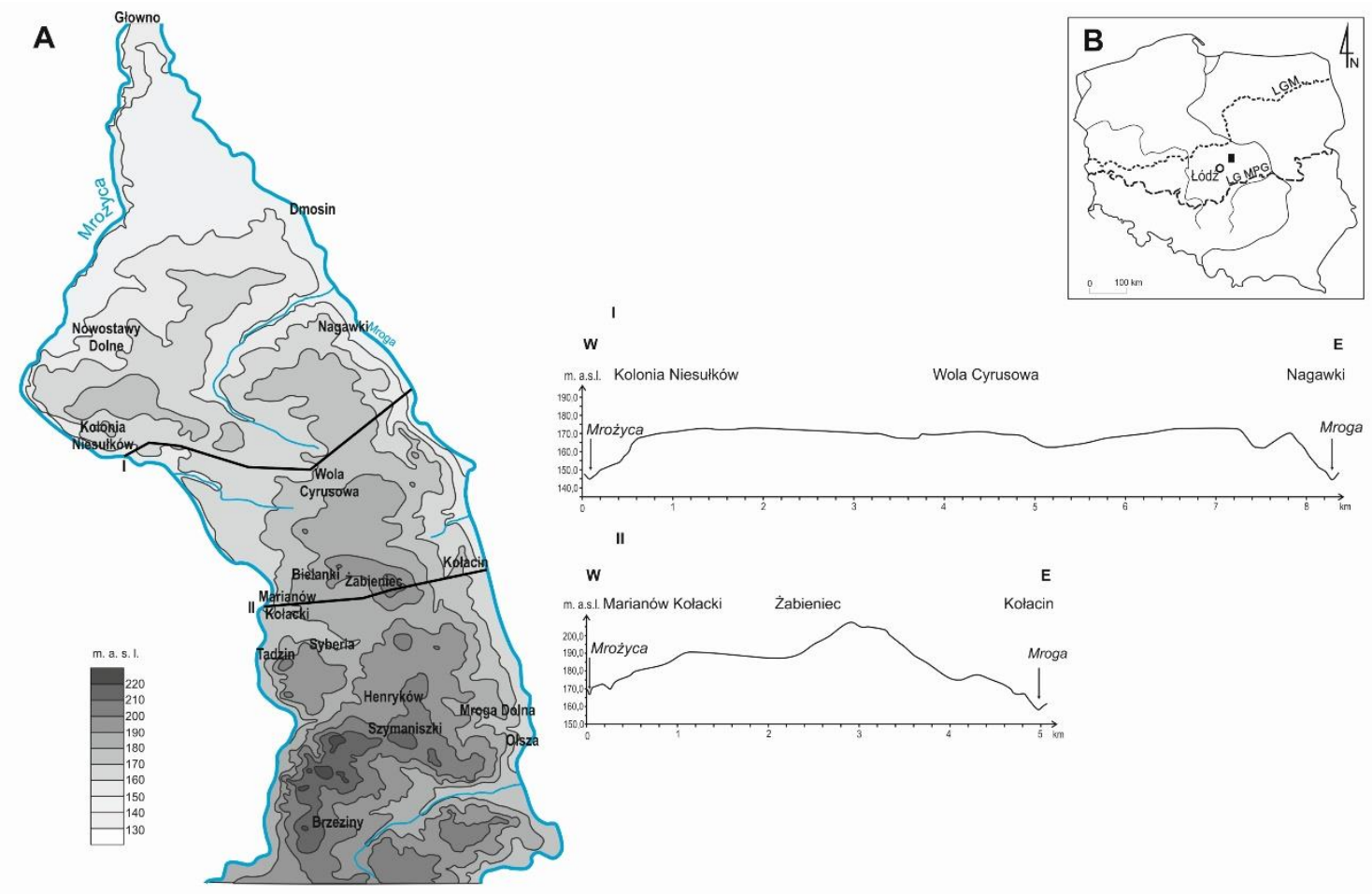

Fig. 2. Mroga and Mrożyca interfluvial area

A - Hypsometry and transversal profiles, B - Location on maximum ranges of Vistula ice sheet (LGM - Last Glacial Maximum) and Warta ice sheet (LG MPG - Late Glacial of Middle Polish Glaciation, according to Lindner, Marks 2012) 


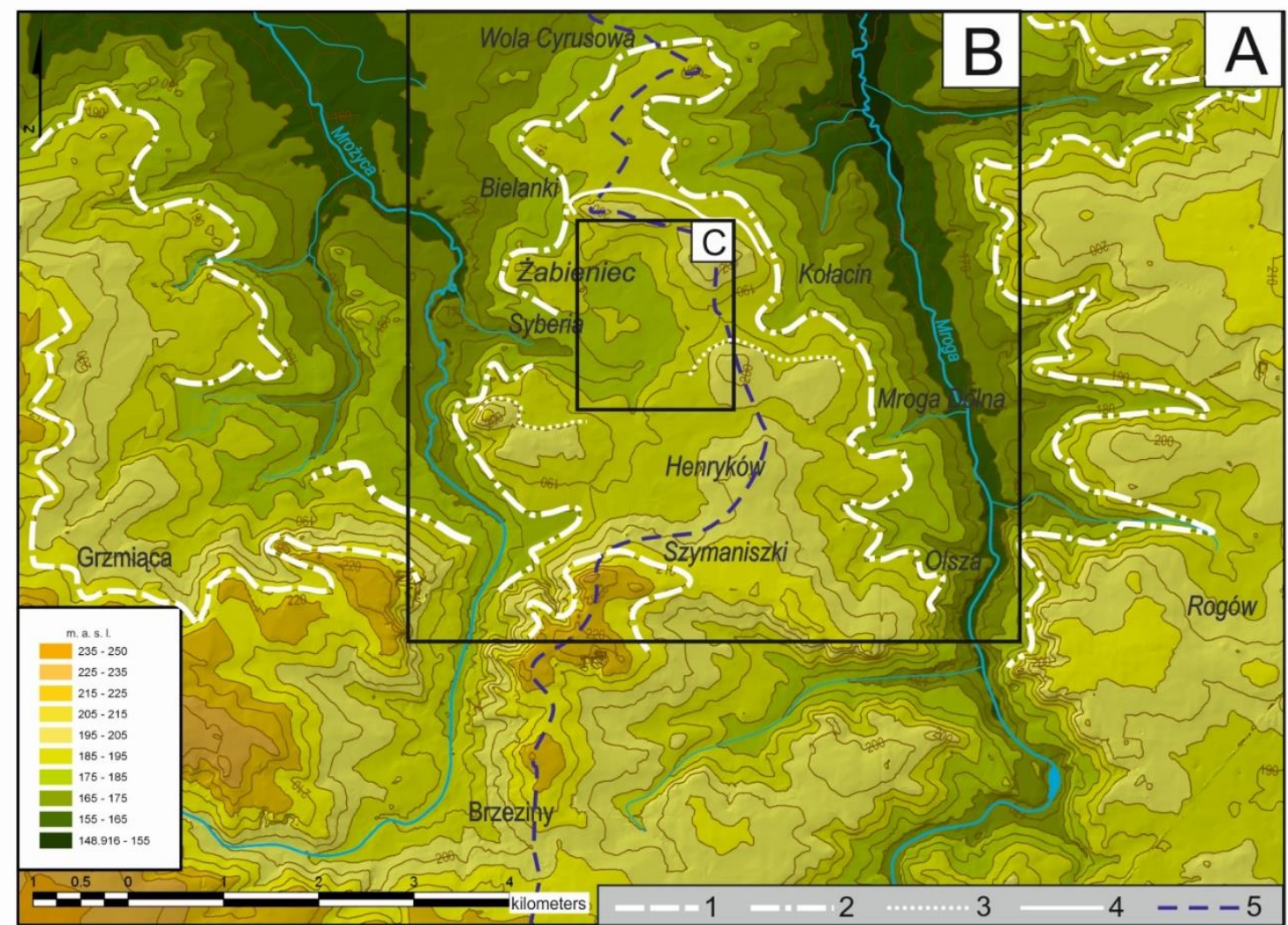

Fig. 3. A - Hypsometric map of a fragment of Mroga and Mrożyca interfluvial area

B - range of geomorphological model (Fig. 6) and land relief energy of denudation valleys (Fig. 10A, 11), $\mathrm{C}$ - range of geological model (Fig. 5) and land relief energy of denudation valleys (Fig. 10B)

1 - Plateau level (I), 2 - Smardzewski level (II) (according to Klatkowa 1965), 3 - Henryków sublevel, 4 - Żabieniec sublevel (according to Turkowska 2007), 5 - watershed (IV) between Mroga and Mrożyca

A $4.3 \mathrm{~km}^{2}$ watershed section near the villages of Żabieniec and Syberia is analysed in more detail in terms of interfluvial relief. This area has been thoroughly researched in the Żabieniec mire (Twardy et al. 2010) and in a fossil lake located south of the mire (Majecka 2012a, b, 2014). It is a closed depression situated directly among the culminations of the plateau area between Mroga River and Mrożyca River. This area is shown on the detailed 3D geological model and map of relief energy of denudation valleys.

\section{Geology}

The entire interfluvial area of the Mroga and Mrożyca is covered with glacial sediments, deposited during the Warta stadial of the Odranian Glaciation (Lindner, Marks 2012). According to the 1:50000 Detailed geological map of Poland (Nowacki 1990, 1993) the general thickness of the Quaternary cover on the interfluvial area is $30 \mathrm{me}-$ tres (in the Mrożyca River valley near Tadzin village) to about 80 metres in the area of fluvioglacial forms (for example to the south-west of Żabieniec). The deposits are predominantly of fluvioglacial sand and gravel of age related to the Warta stadial of the Odranian Glaciation. Near Siberia and Kołacin their thickness exceeds 20 metres. In addition to these deposits, glacigenic till, sand and gravel were documented. In the southern part of interfluvial area, till is present directly on the surface of the highest forms and also often along the left bank of the Mroga River, where it occurs in zones of erosion undercuts forming high slopes. According to Nowacki $(1990,1993)$, the till thickness is insignificant; it reaches 5 to 7 metres, or 5 to 15 metres according to Rdzany (2009).

Vistulian sediments constitute the surface sediments of the Mroga and Mrożyca valleys and numerous denudation forms cutting the moraine plateau. The valley levels of the Mroga and Mrożyca are built of Plenivistulian sand and gravel sediments and sand-gravel sediments and, boulders from the Late Vistulian (Turkowska 1975, 1976, 1988). The lithological research conducted within 
morphologic analyses made it possible to document the scale of the denudation transformation of the landform of a section of the interfluve (Twardy et al. 2010; Majecka 2012a, b). Glacial origin deposits build the upper parts of the slope. Bottoms of denudation valleys, similarly to the bottom of the watershed depressions, are covered with sandy and loamy diluvial sediments. Holocene deposits represented by organic-mineral silt and peat constitute the surface layer in the Żabieniec mire (Fig. 4).

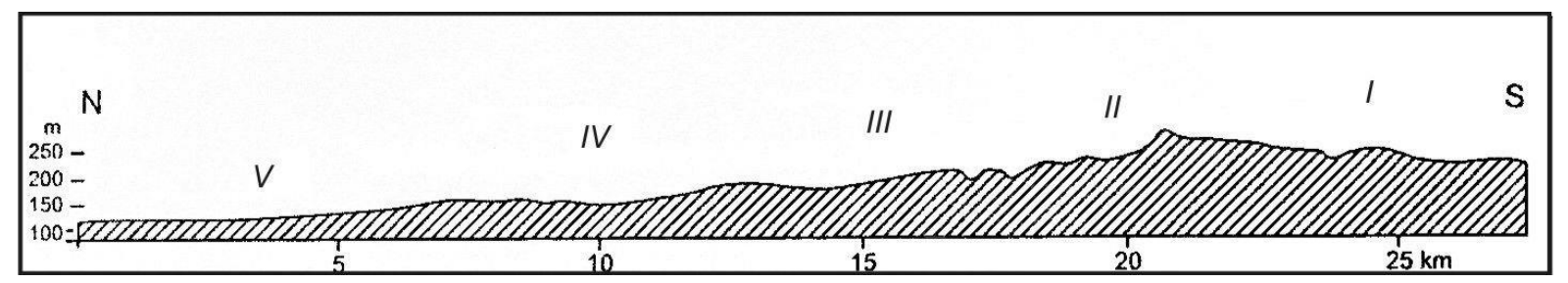

Fig. 4. Geological model of fragment of Mroga and Mrożyca interfluvial area (according to Twardy et al. 2010, modified)

I - Plateau level, II - Smardzewski level, III - Strykowski level, IV - Katarzynowski level, V - Woli Mąkolskiej level

\section{Land relief and its origin}

The land relief of the Mroga and Mrożyca interfluvial area is characterised by both longitudinal variability and latitudinal zonation. The longitudinal variability results from a transition through consecutive forms of valleys, starting from the bottom, through successive morphological valley levels to the plateau area. The latitudinal variability, on the other hand, results from a transition to consecutive levels of the Lódź Plateau edges. This particular feature of the relief of the northern border of the Łódź Plateau was first described by Lencewicz (1927). The author included characteristic, cascade levels in his Morphological map of the central Powiśle district. He also associated the existence of the edge between the Lódź Plateau and the Warsaw-Berlin proglacial stream valley with tectonic origin, and explained the formation of the consecutive levels as an effect of erosion and denudation processes. Following the interpretation of Klatkowa (1965), particular levels separated by steps of the edge zone the Łódź Plateau were formed in the glacial environment as an effect of advances by the Warta ice sheet transgressing over the high-altitude area of the Mesozoic substrate, which was a barrier for the glacier front. Depending on the dynamics of the ice mass inflow, the glacier pushed sediments over an obstacle, causing them to pile up. The first Plateau level (I), including areas elevated above $210 \mathrm{~m}$ a.s.l. The lower Smadzewski level (II) covers the zone in the ordinate range $185-210 \mathrm{~m}$ a.s.l. The next Strykowski level (III) is located between 165-180 m a.s.l. and lower Katarzynowski level (IV) is located between $140-160 \mathrm{~m}$ a.s.l. The fifth and the lowest level of Wola Mąkolska is located between 117-137 $\mathrm{m}$ a.s.l., and is also part of the highest accumulation level of the Warsaw-Berlin proglacial stream valley (Fig. 5) (Klatkowa 1965).

One feature of the longitudinal variability of the relief in the Mroga and Mrożyca valleys is the occurrence of low and high valley levels. The valley levels are the most important forms of the periglacial relief associated with the Plenivistulian (high level) and Late Vistulian (low level). The course and parameters of the Mroga River valley levels have been documented in detail by Turkowska (1975, 1996).

The low level in the valleys of both rivers occurs fragmentarily, and only on the western side. In the Mroga River valley, south of Nagawki and Dmosin villages, the width of the preserved fragments of the low terrace reaches a few tens of metres, and the slope gradient does not exceed $2^{\circ}$. Thus, due to their insignificant size, their presence in the contemporary relief is not conspicuous. The higher valley level is well preserved in both valleys. It consists of two overlying levels the older level of a high terrace covered with younger terrace sediments. It plays a significant role in the varied relief of the Mroga drainage area. During the Upper Plenivistulian, valley slopes were exposed to the strongest denudation processes. 

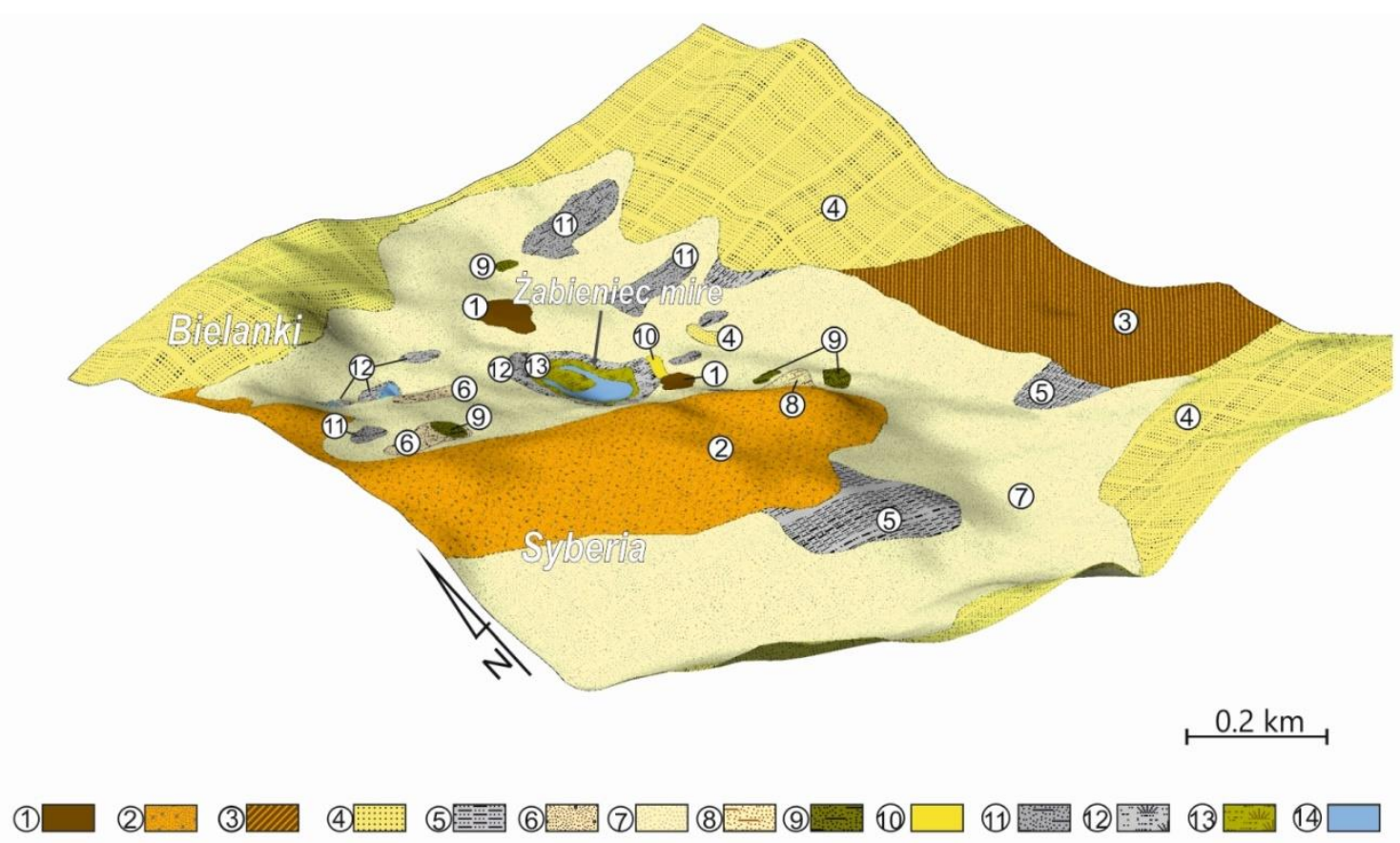

Fig. 5. Levels of edge zone of Łódź Plateau (according to Klatkowa 1965)

1 - Wartanian till, 2 - glacial gravel and sands, 3 - various glacial mineral materials, 4 - fluvioglacial gravel and sands, 5 - diluvial silt, 6 - multifractional sands, 7 - diluvial sands, 8 - diluvial silt with admixture of sands, 9 - silt of closed depressions, 10 - aeolian sands, 11 - diluvial sand with admixture of silt on top of organic deposits, 12 - mineral-organic silt, 13 - peat, 14 - water

The height of the higher valley level reaches 12 metres, and the width ranges from approximately 200 to 500 metres. It becomes wider in the areas of outlets into lateral valleys. In the Mrożyca River valley, the higher level of accumulation occurs on the right, eastern side of the valley. Its slope is characterised by a diversity and a steeper slope compared to the gentle, straight south-western slope. In the upper section of the valley, its width reaches 150 metres. In the section north of Kolonia Niesułków village, where the river changes direction from westwards to north-westwards, the level disappears and becomes wider in the longitudinal section of the valley.

The borders between the plateau and the valley elements are not clear in many places due to the multiplicity of denudation forms combining the high valley level with areas of the highest altitude. The watershed creates a sequence of elevations that are more compact in the south, and become fragmented or disappear in the north. In the landscape of the southern part, it occurs as a separate elevation divided by $\mathrm{E}-\mathrm{W}$ depressions. They serve as a starting point for the denudation systems developed on the slopes. The highest part of the watershed is in the south-western part of the interfluvial region, between Szymaniszki village and Brzeziny. To the east, the watershed is divided by a deep valley with a radial outlet into the Mroga
River below Olsza village. The valley near Syberia village has a similar pattern. These valleys represent the greatest variety of the interfluvial land relief and there are no other valleys cutting so deeply the dense, longitudinal part of the plateau. There is no explanation so far as to why the most favourable conditions for the development of crosswise erosion forms occurred in these places. The fossil closed depressions documented in the upper section of the valley in Syberia are identified as factors initiating the processes of denudation and the development of valley forms. Thus, it may be assumed by analogy that fossil closed depressions are likely to occur in the upper part of the valley running south of Olsza village, representing the primary factor initiating the origin of the valley (Fig. 6). Currently, they are not visible in the morphology of the interfluvial area.

Based on a 1:10 000 geomorphological sketch (Twardy et al. 2010), a 3D geomorphological model was generated for the analysed fragment of the Mroga and Mrożyca interfluvial area (Fig. 6). The watershed culmination comprises forms of glacial relief formed during the ice sheet recession phase. An important element of the watershed relief is the Żabieniec basin with the Żabieniec mire at its centre. The Żabieniec basin was formed due to melting of dead ice blocks during the final phase of the Warta stadial (Nowacki 1993; Twardy et al. 
2010; Majecka et al. 2018). It is surrounded by glacial forms, to the north-east by morainic hills and crevasse landforms 5-13 metres high, and a morainic wave plain (5-9 metres height) to the west.
Morainic hills are intersected with fluvioglacial plains to the south. Numerous denudation forms on the slopes of glacial forms result from the transformation of the original glacial surface.

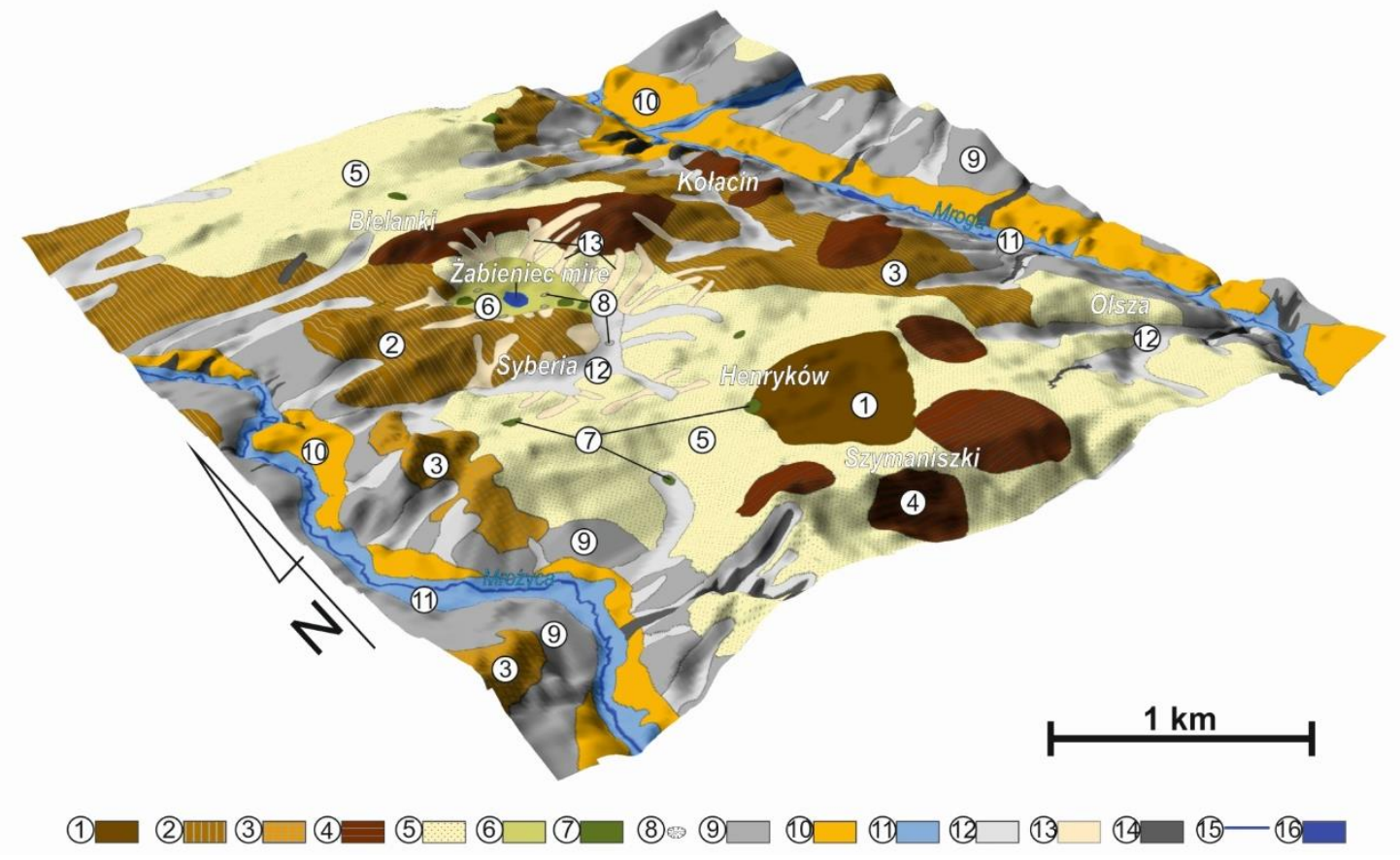

Fig. 6. Geomorphological model of Mroga and Mrożyca interfluvial area (according to Nowacki 1993; Twardy et al. 2010, modified)

1 - flat moraine plains, 2 - undulating moraine plains, 3 - morainic hills, 4 - morainic mounds, 5 - fluvioglacial plains, 6 - melt-out depression, 7 - visible closed depressions, 8 - completely filled closed depressions, 9 - slopes of river valleys, 10 - upper valley level, 11 - bottoms of river valleys, 12 - denudation basins and valleys, 13 - younger denudation valleys, 14 - gullies, 15 - rivers, 16 - waters

\section{Results}

The morphological profile generated using a Digital Elevation Model (DEM) shows in detail the latitudinal variability of the Mroga and Mrożyca interfluvial area. The southern part of the interfluvial is located within two levels of the edge zone of the Łódź Plateau (Fig. 7). The boundary between the Lódź Plateau (I) and the Smardzewski level (II) runs south of Szymaniszki village, at an elevation of 210 $\mathrm{m}$ a.s.l., across the slopes of the Łódź Plateau, to Brzeziny. The lower, extensive Smardzewski level has a triangular outline (Fig. 3). Its northernmost part is located near Wola Cyrusowa at an elevation of $175 \mathrm{~m}$ a.s.l. It is characterised by considerable segmentation. There is a clear division into two arches of elevations running parallel to each other and crosswise to the valleys of the Mroga and Mrożyca rivers. The internal area of the arches of the watershed hills is covered by a landlocked depression and its extension in the form of a denuda- tion valley running westwards - towards the Mrożyca River. To the east - towards the Mroga River valley - there is an extensive denudation valley, which has its origin in the depression of the watershed (Fig. 6).

Based on the extent of denudation of the plateau relief, the examples of which include parallel systems of denudation valleys, Turkowska distinguished two clearly outlined sublevels within the Smardzewski level - Żabieniec and Henryków (Turkowska 2007). The sublevel of Żabieniec is characterised by a lower altitude and greater fragmentation than the other level. Gentle slopes of morainic hills and a sandur plain in the south are separated by denudation forms with varying levels of development. The northern border of the Żabieniec sublevel runs along a range of elevations with an altitude of up to $200 \mathrm{~m}$ a.s.l. The Henryków sublevel is characterised by elevations reaching on average 204-205 m a.s.l. In the south, it is bordered by a slope of the Plateau level (I) near Szymaniszki village (Fig. 7). 


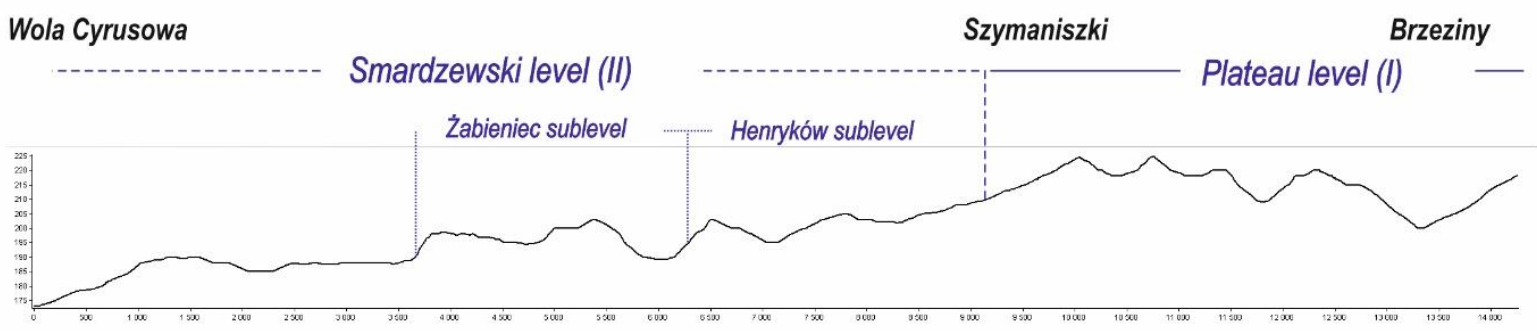

Fig. 7. Morphological profile along line of Mroga and Mrożyca watershed on Brzeziny-Wola Cyrusowa section, generated using DEM (profile line No. 5 on Fig. 3)

The longitudinal variability of the land relief of the Mroga and Mrożyca valleys is expressed by the clear asymmetry of the slope gradient model (Fig. 8). The valley slopes with western exposure are shorter and steeper than the slopes with eastern exposure (Fig. 9). The former are characterised by a gradient of over $10^{\circ}$, while the average gradient of the latter does not exceed $2^{\circ}$. The slopes of the Mroga River valley in the vicinity of Olsza reach gradients of over $12^{\circ}$. Most slopes in the interfluvial area are exposed to higher temperatures: S, SW and W Slopes with a gradient of less than $2^{\circ}$ cover $77 \%$ of the analysed fragment of the watershed (Table 1). The slopes exposed to higher temperatures (S, SW, W) represent $49 \%$ of the area (Table 2).
The bottoms of the Mroga and Mrożyca valleys have varying widths in different fragments, ranging from 50 to 500 metres. The land relief becomes more gentle towards the north and the width of the valley bottoms increases. Compared to the Mroga River, the bottom of the Mrożyca valley is much narrower. In the narrow stretches, the Mrożyca bottom is limited by high edges reaching 4 metres, and steep slopes with a gradient of over $10^{\circ}$. The width of the bottoms of both valleys increases along the sections with a gentle land relief in flattened areas, whereas in areas with steeper slopes (edges of the horizons), the valley bottoms become narrower.

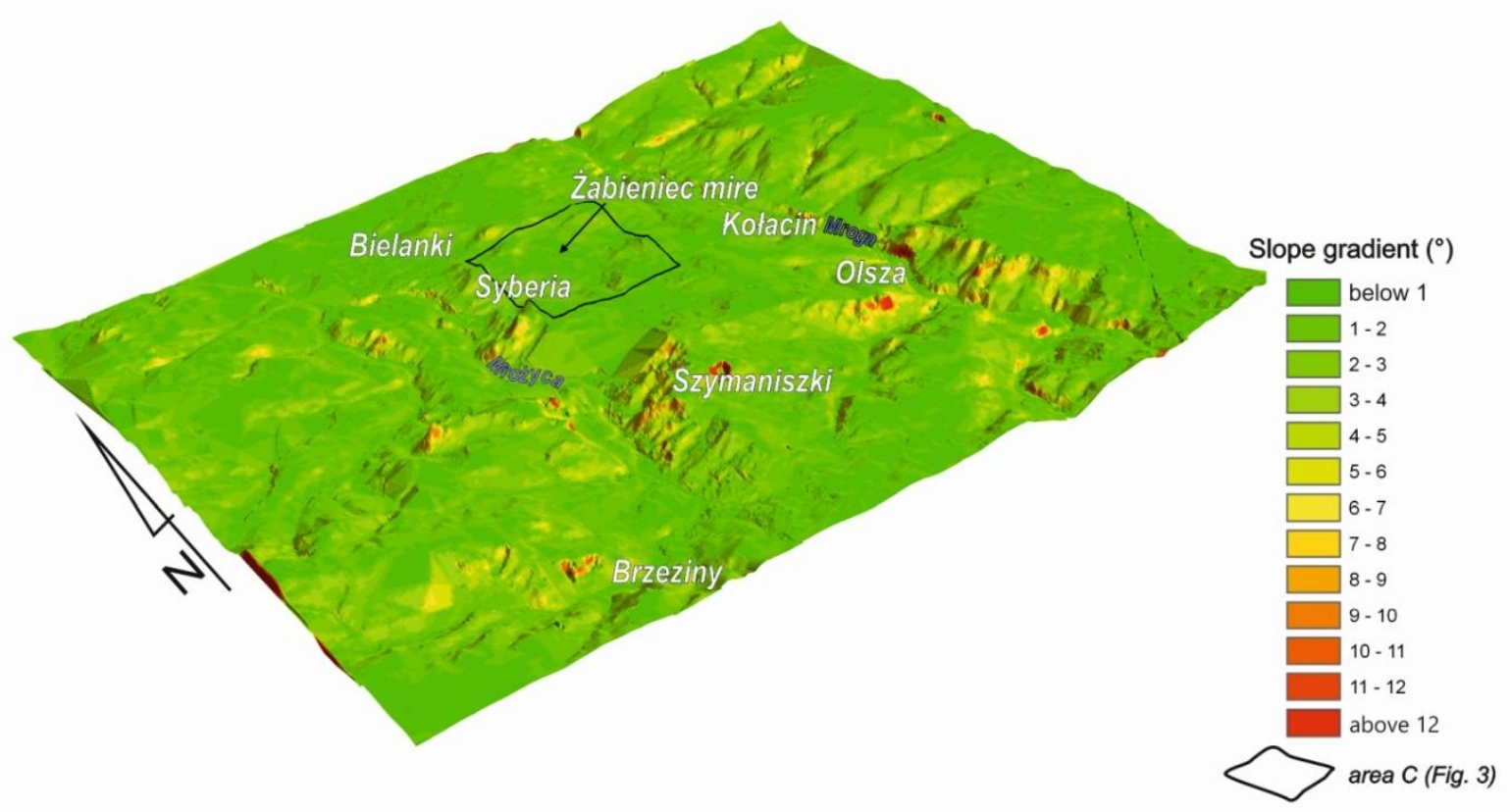

Fig. 8. Gradient of slopes of Mroga and Mrożyca interfluvial area 


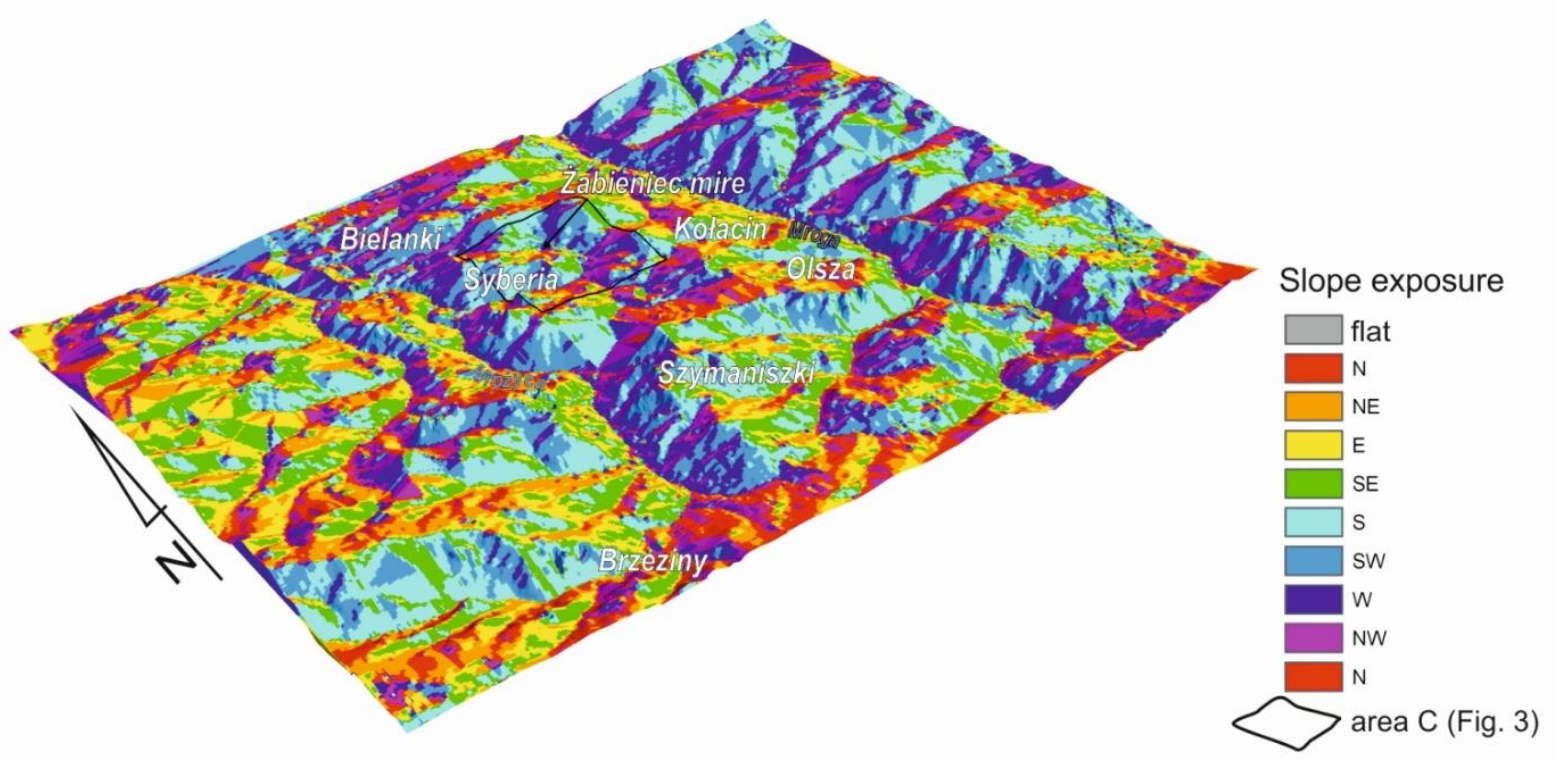

Fig. 9. Slope exposure of Mroga and Mrożyca interfluvial area

Table 1

Gradient of slopes in Mroga and Mrożyca interfluvial area (\%)

\begin{tabular}{|c|c|c|}
\hline Gradient $\left(^{\circ}\right)$ & Surface (ha) & $\%$ \\
\hline $0-1$ & 167.19 & 34.58 \\
\hline $1-2$ & 203.19 & 42.03 \\
\hline $2-3$ & 92.63 & 19.16 \\
\hline $3-4$ & 14.38 & 2.97 \\
\hline $4-5$ & 3.19 & 0.66 \\
\hline $5-6$ & 1.69 & 0.35 \\
\hline $6-7$ & 0.19 & 0.04 \\
\hline $7-8$ & 0.19 & 0.04 \\
\hline $8-9$ & 0.13 & 0.03 \\
\hline $9-10$ & 0.50 & 0.10 \\
\hline $10-11$ & 0.19 & 0.04 \\
\hline TOTAL: & 483.44 & 100.00 \\
\hline
\end{tabular}

Table 2

Exposure of slopes in Mroga and Mrożyca interfluvial area (\%)

\begin{tabular}{|c|c|c|c|}
\hline Slopes exposure & Gradient $\left(^{\circ}\right)$ & Surface (ha) & $\%$ \\
\hline $\mathrm{N}$ & $0-22.5$ & 48.00 & 9.93 \\
\hline $\mathrm{NE}$ & $22.5-67.5$ & 55.94 & 11.57 \\
\hline $\mathrm{E}$ & $67.5-112.5$ & 23.06 & 4.77 \\
\hline $\mathrm{SE}$ & $112.5-157.5$ & 39.56 & 8.18 \\
\hline $\mathrm{S}$ & $157.5-202.5$ & 76.69 & 15.86 \\
\hline $\mathrm{SW}$ & $202.5-247.5$ & 89.06 & 18.42 \\
\hline $\mathrm{W}$ & $247.5-292.5$ & 70.00 & 14.48 \\
\hline $\mathrm{NW}$ & $292.5-337.5$ & 50.13 & 10.37 \\
\hline $\mathrm{N}$ & $337.5-360$ & 31.00 & 6.41 \\
\hline \multicolumn{2}{r}{ TOTAL: } & 483.44 & 100.00 \\
\hline
\end{tabular}


Analysis of the land relief energy was conducted for different denudation forms, highlighting the extent of their development in relation to one another. The best developed forms with the greatest land relief energy (25.1-43.7) occur on the western slope of the Mroga River (Fig. 10A), which results from the intensity of denudation processes in the Vistulian period on humid, "cold" slopes. These are usually the longest forms, but also a short form in the vicinity of Mroga Dolna is characterised by the highest energy. Such a situation occurs also in the valley running into the Mroga near Kołacin. A system of denudation valleys located in the upper section of the Mrożyca River is characterised by the highest land relief energy. The greatest breakup of the watershed occurs near Syberia, where extensive denudation forms have their origin in the upper section of both the western and eastern slope, between which a valley watershed was formed. Analysis of the land relief energy conducted within the drainage basin of the depression confirms the existence of forms with the highest land relief energy (15-11.4) on the northern and eastern slopes of the watershed, steeper and built primarily of loose sediments (Fig. 10B).

The analysis of the relief energy was conducted also for a grid of $200 \times 200 \mathrm{~m}$ squares covering the entire area corresponding to six DEM sheets (Fig. 11). It shows that the largest differences in height occur primarily in the lower parts of the eastern slopes of the Mroga and Mrożyna valleys. Both variants of the land relief analysis captured a very distinct field energy in the vicinity of Syberia, at the estuary of the denudation valleys into the Mrożyca where a morainic inlier is located.

\section{Discussion}

The popularity of GIS methods in the recent geomorphological analyses necessitates the use of these methods for areas whose land relief and genesis have already been recognised. Such an approach makes it possible to update the cartographic documentation of areas studied a long time ago, but also to verify the views on the prominence of certain land relief features and their importance. As part of the visualisation update as well as an attempt to verify the palaeogeomorphological concept of Klatkowa $(1965,1972,1996$; Turkowska 1975 ) in the GIS environment, maps of the escarpment zone of the Łódź Plateau have recently been prepared based on a free Digital Elevation Model
SRTM-3 (Szmidt 2013). The conducted collation confirmed the hypothesis concerning the existence and separation of steps of the edge zone of the Łódź Plateau, but it also made it clear that the Digital Elevation Model SRTM-3 may be the basis for geomorphological analyses only to a limited extent. Similar observations come to mind after this analysis of the land relief of the Mroga and Mrożyca interfluvial area representing a fragment of the escarpment zone; the analysis was based on the Triangulated Irregular Network (TIN) built on an irregular grid of triangles set on measurement points. The contemporary cartographic processing techniques did not restrain the recognition of the land relief. Moreover, the quality of the archival cartographic works, despite the lack of advanced techniques, did not differ in terms of details and quality from the maps prepared with the use of the contemporary techniques. Archival research of the Mrożyca catchment is highly detailed. New techniques allow the data to be refined by entering georeferencing into the coordinate system and allow for statistical analysis. Generally available data allows you to visualize the data depending on the needs.

$3 \mathrm{D}$ modelling is a technique that is currently bringing something new to geomorphological analyses. Visualisations are extremely useful in analysing various parameters. At present, visualisations are the most popular method of creating and presenting information. The three-dimensional representations prepared for the interfluvial area present a new perspective on this area by facilitating a more detailed analysis of the land relief variability and conditions. The plasticity of the surface presented in the geomorphological and geological models enhanced the relationships between the surface geological structure and land relief. Digital models of depressions and land exposure allowed quantitative morphometric analysis of these land relief features, reducing the probability of mistakes or subjectivity in measurements. Consequently, these methods might revise many ideas in the field of geomorphology. They also guarantee the repeatability and comparability of results. Analysis of land relief energy, especially one conducted for specific land relief parameters, represents a new perspective on their old classification. For the study area, the analysis was conducted for denudation forms with a varying degree of development, being one of the most important features of the land relief. This imaging analysis partly corroborated the view that they are more developed on western (cold) slopes, yet it also showed no correlation between the length of 

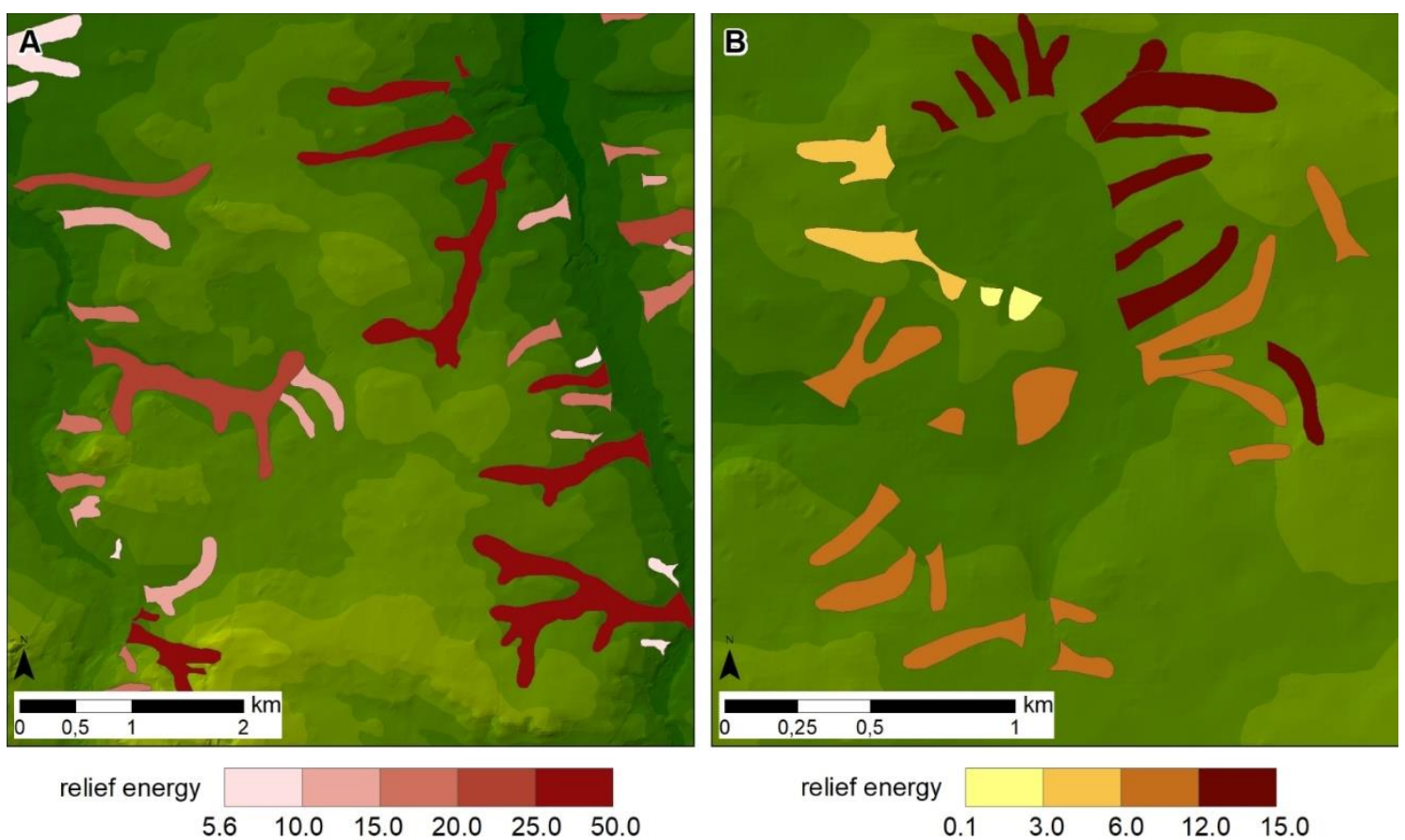

relief energy

$\begin{array}{llllll}5.6 & 10.0 & 15.0 & 20.0 & 25.0 & 50.0\end{array}$

$\begin{array}{lllll}0.1 & 3.0 & 6.0 & 12.0 & 15.0\end{array}$

$\begin{array}{lllllllllll}150.0 & 160.0 & 170.0 & 180.0 & 190.0 & 200.0 & 210.0 & 220.0 & 230.0 & 240.0 & 250.0 \text { m. a. s. I. }\end{array}$

Fig. 10. Land relief energy of denudation valleys (in metres): A - in Mroga and Mrożyca interfluvial area (range area B, see Fig. 3), B - in section of watershed (range area B, see Fig. 3)

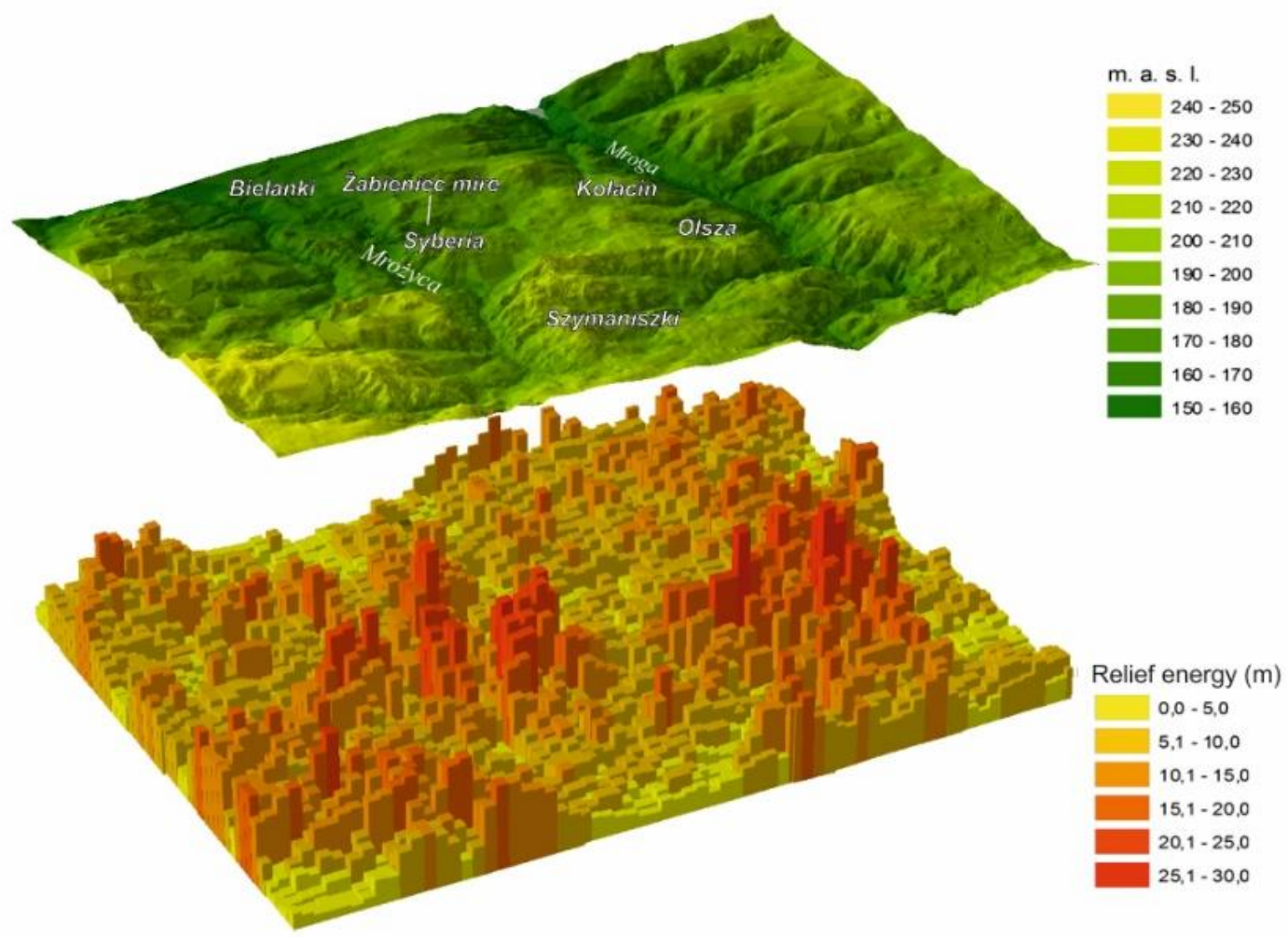

Fig. 11. Relief energy (in metres) for square units of $200 \times 200 \mathrm{~m}$ 
the forms and their energy. Furthermore, it highlighted the relationship between the occurrence of denudation forms and geological structure, which was presented in the analysed watershed fragment where more denudation forms are located on the eastern and northern slopes of the watershed depression, built of fluvioglacial, sandy and gravel sediments, than on glacial slopes built of compact sediments or with an admixture of compact sediments.

\section{Conclusions}

- GIS spatial analysis is useful for detail geomorphological interpretation, for example, of area, actual distance, frequency, exposure or slope gradient; however, what are crucial are field studies that allow for accurate recognition of surface geological structure and its relationship with the morphogenesis of the relief.

- Multi-variant GIS analysis generates land relief parameters to allow precise conclusions as well as a confirmation, reinterpretation or revision of existing palaeogeographic concepts.

- Numerous denudations valleys are more developed on western (cold) slopes, yet there is no correlation between the length of the forms and relief energy.

- The maps and three-dimensional GIS models show a new perspective of the land relief of the Mroga and Mrożyca interfluvial area and are a starting point for further research on the factors and stages of its development.

- However, the quality of the archival cartographic works, despite the lack of advanced techniques, did not differ in terms of detail and quality from the maps prepared with the use of contemporary techniques.

\section{Acknowledgments}

The authors thank the Reviewers for their insightful comments. This is a contribution to the research Project funded by the National Science Centre (2014/15/B/ST10/03809) in Poland.

\section{References}

Dylik J. 1953. O peryglacjalnym charakterze rzeźby środkowej Polski. Acta Geographica Universitatis Lodziensis 4.

Dylik J. 1961. Guide-book of Excursion C. The Łódź region. VIth INQUA Congress, Poland.
Dylik J. 1967. Główne elementy paleogeografii młodszego plejstocenu Polski Środkowej. In: R. Galon, J. Dylik (eds) Czwartorzęd Polski. PWN, Warszawa: 311-352.

Franklin S. 1987. Geomorphometric processing of digital elevation models. Computers \&Geosciences 13(6): 603-609.

Groshong Jr. R.H. 2006. 3-D Structural Geology. A Practical Guide to Quantitative Surface and Subsurface Map Interpretation. Springer, Berlin Heidelberg.

Klatkowa H. 1965. Niecki i doliny denudacyjne w okolicach Lodzi. Acta Geographica Lodziensia 19.

Klatkowa H. 1972. Paleogeografia Wyżyny Łódzkiej i obszarów sąsiednich podczas zlodowacenia warciańskiego. Acta Geographica Lodziensia 28.

Klatkowa H. 1996. Elementy glacitektoniczne w budowie geologicznej i rzeźbie podłódzkiej części środkowej Polski. Acta Geographica Lodziensia 73.

Lencewicz S. 1927. Dyluwium i morfologia środkowego Powiśla. Prace Państwowego Instytutu Geologicznego 2(2): 66-194.

Lindner L. Marks L. 2012. O podziale klimatostratygraficznym kompleksu środkowopolskiego w plejstocenie Polski. Przegląd Geologiczny 60(1): 36-45.

Majecka A. 2012a. Geological structure and sediments of a closed basin within the watershed between the Mroga and Mrożyca rivers. In: J. Forysiak, L. Kucharski, M. Ziułkiewicz (eds) Peatlands in semi-natural landscape-their transformation and the possibility of protection. Bogucki Wyd. Nauk., Poznań: 123-134.

Majecka A. 2012b. Postwarciańskie przekształcenia rzeźby obszarów wododziałowych na Wysoczyźnie Łódzkiej (na przykładzie międzyrzecza Mrogi i Mrożycy). Doctoral manuscript.

Majecka A. 2014. The Palynological Record of the Eemian Interglacial and Early Vistulian Glaciation in Deposits of the Żabieniec Południowy Fossil Basin (Łódź Plateau, Central Poland), and its Palaeogeographic Significance. Acta Palaeobotanica 54(2): 279-302. DOI: 10.2478/acpa2014-0007.

Majecka A., Balwierz Z., Forysiak J., Twardy J. 2018. Eemian and Vistulian (Weichselian) development of the meltout depression on the watershed between the Mroga and Mrożyca Rivers (Central Poland) based on lithological and pollen analysis. Quaternary International, Part A 467: 79-95. https://doi.org/10.1016/j.quaint.2016.08.012

Medyńska-Gulij B. 2012. Kartografia i geowizualizacja. Wyd. Nauk. PWN: Warszawa.

Nita J., Małolepszy Z., Chybiorz R. 2007. Zastosowanie numerycznego modelu terenu do wizualizacji rzeźby terenu i interpretacji budowy geologicznej. Przegląd Geologiczny 55(6): 511-520. 
Nowacki K. 1990. Szczegółowa mapa geologiczna Polski w skali 1:50 000, ark. Łyszkowice, (592). Państwowy Instytut Geologiczny, Warszawa.

Nowacki K. 1993. Objaśnienia do Szczegółowej mapy geologicznej Polski w skali 1:50 000, ark. Łyszkowice (592). Państwowy Instytut Geologiczny, Warszawa.

Numeryczny model terenu, arkusze: M-34-4-A-d-4, M34-4-B-c-3, M-34-4-B-c-4, M-34-4-C-b-2, M34-4-D-a-1, M-34-4-D-a-2.

Pike R., Evans I., Hengl T. 2009. Geomorphometry: A brief guide. In: T. Hengl, H. Reuter (eds) Geomorphometry: Concepts, Software, Applications. Elsevier: 3-30.

Raper J. (ed.) 1989. Three dimensional applications in Geographical Information Systems. CRC Press.

Rdzany Z. 2009. Rekonstrukcja przebiegu zlodowacenia warty w regionie łódzkim. Wyd. UŁ, Łódź.

Szmidt A. 2013. Strefa krawędziowa Wzniesień Łódzkich w świetle badań GIS. Acta Universitatis Lodziensis. Folia Geographica Physica 12: 83-95.

Turkowska (Kuydowicz-) K. 1975. Rzeczne procesy peryglacjalne na tle morfogenezy doliny Mrogi. Acta Geographica Lodziensia 36.

Turkowska K. 1976. Typy kontaktów peryglacjalnych osadów stokowych i rzecznych. Acta Geographica Lodziensia 37: 127-136.
Turkowska K. 1988. Rozwój dolin rzecznych na Wyżynie Łódzkiej w późnym czwartorzędzie. Acta Geographica Lodziensia 57.

Turkowska K. 1996. Przykłady dolin poligenicznych w regionie łódzkim. Acta Geographica Lodziensia 71: 243-258.

Turkowska K. 1997. Niesułków. Rzeźba doliny i struktura strefy brzeżnej wysokiego poziomu dolinnego Mrożycy. Konferencja robocza „Środkowoplenivistuliańskie osady w małych dolinach rzecznych”. Łódź 6-8 V 1997: 37-39.

Turkowska K. 2007. Rzeźba i struktura wypełnień dolin górnej Mrogi i Mrożycy jako świadectwo polodowcowych etapów ewolucji międzyrzecza. Acta Geographica Lodziensia 93: 87-105.

Twardy J., Żurek S., Forysiak J. (eds) 2010. Torfowisko Żabieniec: warunki naturalne, rozwój i zapis zmian paleoekologicznych w jego osadach. Bogucki Wyd. Nauk., Poznań.

Urbański J. 2012. GIS w badaniach przyrodniczych (ebook). Centrum GIS, Uniwersytet Gdański, Gdańsk.

Wieczorek M., Żyszkowska W. 2011. Geomorfometria - parametry morfometryczne w charakterystyce rzeźby terenu. Polski Przegląd Kartograficzny 43(2): 130-144.

Żyszkowska W., Spallek W., Borowicz D. 2012. Kartografia tematyczna. Wyd. Nauk. PWN, Warszawa. 